\title{
A Review of Bio-lubricant Production from Vegetable Oils Using Esterification Transesterification Process
}

\author{
Arianti N. Annisa, ${ }^{1, *}$ and Widayat Widayat ${ }^{1,2}$ \\ ${ }^{1}$ Department of Chemical Engineering, Faculty of Engineering, Diponegoro University, Semarang \\ ${ }^{2}$ Laboratory of Material Technology, Centre of Research and Service Diponegoro University, Semarang
}

\begin{abstract}
Since long time ago, petroleum oil has been used as a lubricant in motor vehicles. But, the uses of lubricants petroleum can pollute the environment and disrupt marine ecosystems and terrestrial. On the other hand, the use of lubricants in the world in 2008 reached 46 million kiloliters/year and increased by $2 \%$ every year. The future prospect the uses of lubricant petroleum on the vehicle's engine is predicted to have a bad prospect. Thus began research to identify suitable materials to replace petroleum based lubricants. It can produce from vegetable oils and animals oils by chemical modification. But, bio-lubricant properties are easily damaged so we need more research to improve the shelf life of the bio-lubricant. The research must be done to improve the characteristics by adding a bio-lubricant additive.
\end{abstract}

\section{Introduction}

In 2025, Indonesia's energy mix is expected to be realized by the use of oil less than $20 \%$ and uses of renewable energy more than 5\% [1]. It aims to improve the management of natural resources and the environment to support the quality of life and to improve the maintenance and use of biodiversity. On the other hand, the automotive industry and the machine began to focus on the improvement of environment-friendly technologies and energy efficient. Technology developed toward the use of fuel with low pollution combustion and exhaust as well as the efficiency of the vehicle is expected to reduce environmental problems [2]. To achieve an environmentally friendly vehicle conditions requiring lubrication in the engine parts so as to reduce friction between each other. By reduced friction, it can reduce energy loss in the engine.

For a long time oil has been used as a lubricant in motor vehicles. Nonetheless, the uses of lubricants petroleum can pollute the environment and disrupt marine ecosystems and terrestrial. On the other hand, the use of lubricants in the world in 2008 reached 46 million kiloliters/year and increased by $2 \%$ every year. In Indonesia, the use of lubricants in 2012 amounted to 2,988,265 barrels and increased $2 \%-8 \%$ annually [3]. However this is not in line with the availability of petroleum which has declined by $3 \%$ annually [3]. Based on Tung and McMillan [4] research, the future prospects the uses of lubricant petroleum on the vehicle's engine is predicted to have a bad prospect. Thus began research to identify suitable materials to replace petroleum based lubricants.

Their depletion of crude oil reserves and demands for protecting the environment by reducing pollution generated from the lubricating oil led to an interest to develop and use alternative lubricants. Bio-lubricant felt can be used as an alternative to replace lubricants from petroleum as it has suitable properties and can be renewed. Compared with a lubricant, bio-lubricant has a high degree of lubricity, high viscosity index, high flash point and low volatility [5-10].

\section{Raw Material of Bio-lubricant}

Bio-lubricant interpreted as a lubricant obtained from natural raw materials both vegetable and animal oils, renewable and non-toxic to humans and other living things, as well as environmentally friendly. Vegetable oil used for the production bio-lubricant can be obtained from plant seeds, such as vegetable oil that can be consumed or which cannot be consume. Some of the vegetable oil can be used as bio-lubricant i.e. castor oil [11], karanja, neem, rice bran, rapeseed, castor, linseed, mahua [12], palm oil [13], sunflower oil, coconut, soybean, olive and canola [14].

The main content of vegetable oils that are important in making bio-lubricant is triglycerides. Triglycerides are glycerol molecules that have three long chain polar fatty acids attached at the hydroxyl groups via ester linkages [15]. But vegetable oils derived from plants have unstable nature. It is influenced by the free acid content in vegetable oil. Therefore, it should be known fatty acid

Corresponding author: ariantinuura@gmail.com 
content in vegetable oil. The fatty acid composition of vegetable oils were listed in Table 1.

Table 1. Fatty acids composition of vegetable oils [15-16]

\begin{tabular}{|c|c|c|c|c|c|}
\hline Vegetable oils & $\begin{array}{c}\text { Palmitic } \\
(16: 0)\end{array}$ & $\begin{array}{c}\text { Stearic } \\
(18: 0)\end{array}$ & $\begin{array}{c}\text { Oleic } \\
(18: 1)\end{array}$ & $\begin{array}{c}\text { Linoleic } \\
(18: 2)\end{array}$ & $\begin{array}{c}\text { Linolenic } \\
(18: 3)\end{array}$ \\
\hline Sunflower oil & 6.1 & 5.3 & 21.4 & 66.4 & - \\
\hline High oleic sunflower oil & 3.5 & 4.4 & 80.3 & 10.4 & - \\
\hline Safflower oil & 6.4 & 2.5 & 17.9 & 73.2 & - \\
\hline High oleic safflower oil & 4.6 & 2.2 & 77.5 & 13.2 & - \\
\hline $\begin{array}{l}\text { High linoleic safflower } \\
\text { oil }\end{array}$ & 6.7 & 2.6 & 14.6 & 75.2 & - \\
\hline Soybean oil & 6.0 & 5.2 & 20.2 & 63.7 & 5.0 \\
\hline High oleic soybean oil & 6.2 & 3.0 & 83.6 & 3.7 & 1.7 \\
\hline Corn oil & 10.6 & 2.0 & 26.7 & 59.8 & 0.9 \\
\hline Cottonseed oil & 18.0 & 2.0 & 41.0 & 38.0 & 1.0 \\
\hline Rapeseed oil & 3.5 & 0.9 & 19.4 & 22.3 & 8.2 \\
\hline Canola oil & 2.5 & 1 & 64.4 & 22.2 & 8.2 \\
\hline Peanut oil & 10 & 3 & 50 & 30 & - \\
\hline Linseed oil & 5 & 3 & 22 & 17 & 52 \\
\hline Olive oil & 14 & 2 & 64 & 16 & 2 \\
\hline Coconut oil & 9 & 2 & 7 & 1 & 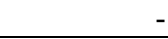 \\
\hline Palm oil & 42 & 5 & 41 & 10 & - \\
\hline
\end{tabular}

By knowing the composition of fatty acids in vegetable oil can affect the characteristics to be generated bio-lubricant. Vegetable oils that have more double chains will have a better pour point and low oxidation stability, whereas the vegetable oils those have less double chains. Lubricants have utility for reducing friction between the surfaces in mutual contact and are used in various applications such as agriculture, forestry, transportation, mining, automobile, fishing, chainsaw oils, transmission oils, serving as engine oils and hydraulic oils [17]. Based on that, it must be known to the comparison between the properties of commercial lubricants and vegetable oils to produce bio-lubricant. Properties of commercial lubricant and vegetable oils listed in Table 2.

Table 2. Characteristics of commercial lubricant and vegetable oils [17]

\begin{tabular}{|c|c|c|c|c|c|c|c|c|}
\hline $\begin{array}{c}\text { Lubricant } \\
\text { requirement }\end{array}$ & $\begin{array}{l}\text { Viscosity } \\
40^{\circ} \mathrm{C} \text { (cSt) }\end{array}$ & $\begin{array}{c}\text { Viscosity } \\
100^{\circ} \mathrm{C} \\
\text { (cSt) } \\
\end{array}$ & $\begin{array}{l}\text { Viscosity } \\
\text { index }\end{array}$ & $\begin{array}{c}\text { Pour point } \\
\left({ }^{\circ} \mathrm{C}\right)\end{array}$ & $\begin{array}{c}\text { Flash } \\
\text { point }\left({ }^{\circ} \mathrm{C}\right)\end{array}$ & $\begin{array}{c}\text { Oxidative } \\
\text { stability } \\
\text { (min) }\end{array}$ & $\begin{array}{l}\text { Coefficient } \\
\text { of friction }\end{array}$ & $\begin{array}{c}\text { Wear scar } \\
\quad(\mathbf{m m})\end{array}$ \\
\hline ISO VG32 & $>28.8$ & $>4.1$ & $>90$ & -6 & 204 & - & - & - \\
\hline ISO VG46 & $>41.4$ & $>4.1$ & $>90$ & -6 & 220 & - & - & - \\
\hline ISO VG68 & $>61.4$ & $>4.1$ & $>198$ & -6 & 226 & - & - & - \\
\hline ISO VG100 & $>90.0$ & $>4.1$ & $>216$ & -6 & 246 & 1670.26 & - & - \\
\hline $\begin{array}{l}\text { Paraffin } \\
\text { VG95 }\end{array}$ & 95 & 10 & 102 & - & - & - & - & - \\
\hline $\begin{array}{l}\text { Paraffin } \\
\text { VG460 } \\
\end{array}$ & 461 & 31 & 97 & - & - & - & - & - \\
\hline R150 & 150.04 & - & - & - & 195 & 931.16 & - & - \\
\hline SAE20W40 & 105 & 13.9 & 132 & -21 & 200 & - & 0.117 & 0.549 \\
\hline AG100 & 216 & 19.6 & 103 & -18 & 244 & - & - & - \\
\hline $75 \mathrm{~W}-90$ & 120 & 15.9 & 140 & -48 & 205 & - & - & - \\
\hline $75 \mathrm{~W}-140$ & 175 & 24.7 & 174 & -54 & 228 & - & - & - \\
\hline $80 \mathrm{~W}-140$ & 310 & 31.2 & 139 & -36 & 210 & - & - & - \\
\hline \multicolumn{9}{|l|}{ Vegetable oil } \\
\hline Soybean & 28.86 & 7.55 & 246 & -9 & 325 & - & - & - \\
\hline Sunflower & 40.05 & 8.65 & 206 & -12 & 252 & - & - & - \\
\hline Passion fruit & 31.78 & - & - & - & 228 & 7.5 & - & - \\
\hline Moringa & 44.88 & - & - & - & 204 & 28.27 & - & - \\
\hline Castor & 220.6 & 19.72 & 220 & -27 & 250 & - & - & - \\
\hline Rapeseed & 45.60 & 10.07 & 180 & -12 & 240 & - & - & - \\
\hline Jatropha & 35.4 & 7.9 & 205 & -6 & 186 & 5 & - & - \\
\hline Coconut & 24.8 & 5.5 & 169 & 21 & 325 & - & 0.101 & 0.601 \\
\hline Rice bran & 40.6 & 8.7 & 169 & -13 & 318 & - & 0.073 & 0.585 \\
\hline Palm & 52.4 & 10.2 & 186 & -5 & - & - & - & - \\
\hline Lesquerella & 119.8 & 14.7 & 125 & -21 & - & - & 0.045 & 0.857 \\
\hline Pennycress & 40.0 & 9.3 & 226 & -21 & - & - & 0.054 & 0.769 \\
\hline
\end{tabular}




\section{Production Process of Bio-lubricant}

Bio-lubricant is a lubricant made from vegetable oil that can reduce environmental pollution [18]. Bio- lubricant produced by modifying the chemical structure of the fatty acid. The method can be performed is lists in Table 3.

Table 3. Chemical Modifications on Fatty Acids [19]

\begin{tabular}{|c|c|}
\hline Modification & Catalyst \\
\hline \multicolumn{2}{|l|}{ Modification of Carboxyl Groups } \\
\hline - Esterification/transesterification & Acids, Bases \\
\hline - Estolides & $\mathrm{HClO}_{4}$ \\
\hline \multicolumn{2}{|l|}{ Modification of fatty acid chains } \\
\hline - Selective hydrogenation & Copper catalysts \\
\hline - Dimerisation/oligomerisation & Aluminosilicates \\
\hline - Diels-Alder cycloaddition & - \\
\hline - Telomerisation & $\mathrm{H}_{2} \mathrm{O}$ vapor \\
\hline - Co-oligomerisation & $\mathrm{RhCl}_{3} \cdot 3 \mathrm{H}_{2} \mathrm{O}$ \\
\hline - Hydroformylation (oxo-synthesis) & $\mathrm{Rh}\left(\mathrm{Ph}_{3} \mathrm{P}\right)_{3}$ \\
\hline - Friedel-Crafts alkylation & $\mathrm{Et}_{3} \mathrm{Al}_{2} \mathrm{Cl}_{3}$ \\
\hline - Aminoalkylation & {$[\mathrm{Rh}(\mathrm{COD}) \mathrm{Cl}]_{2}$} \\
\hline - Friedel-Crafts acylation & $\mathrm{EtAlCl}_{2}$ \\
\hline - Ene-reaction & $\mathrm{EtAlCl} 2, \mathrm{SnO}_{4}$ \\
\hline - Radical addition & $\mathrm{Mn}(\mathrm{OAc})_{3}, \mathrm{Cu}$ \\
\hline - Acyloxylation & Nafion $/ \mathrm{SiO}_{2}$ \\
\hline - Cyclopropanation & $\mathrm{CH}_{2} \mathrm{I}_{2}, \mathrm{Zn}(\mathrm{Cu}), \mathrm{Et}_{2} \mathrm{Zn}$ \\
\hline - Metathesis & Grubbs catalyst \\
\hline - Epoxidation & Peracids, chemo-enzymatic \\
\hline - Ozonation & - \\
\hline - Oxidative cleavage & $\mathrm{Pb}_{3} \mathrm{O}_{4}$ \\
\hline
\end{tabular}

\section{Esterification/Transesterification}

Esterification process is a method to produce ester (RCOOR') by reacting a compound of acid and alcohol by eliminating the water formed in the reaction product. The molecular structure that reacts affect reaction rates, in particular molecular structure that acts as a free radical. The acid catalysts are often used is a strong mineral acid, such as hydrochloric acid and sulfuric acid. Also, it can use other materials such as silica gel, and cation resin exchanger. Biopelumas formation mechanism esterification reaction can be seen in Figure 1.

Fig. 1. Esterification of fatty acids [20]

While the process of converting vegetable oil (triglyceride ester) into bio-lubricant (triesters) known as transesterification process, the reaction between triglycerides as a component of vegetable oil with 
alcohol octavalen, using a base catalyst. The mechanism of the production biopelumas transesterification reaction is shown in Figure 2.

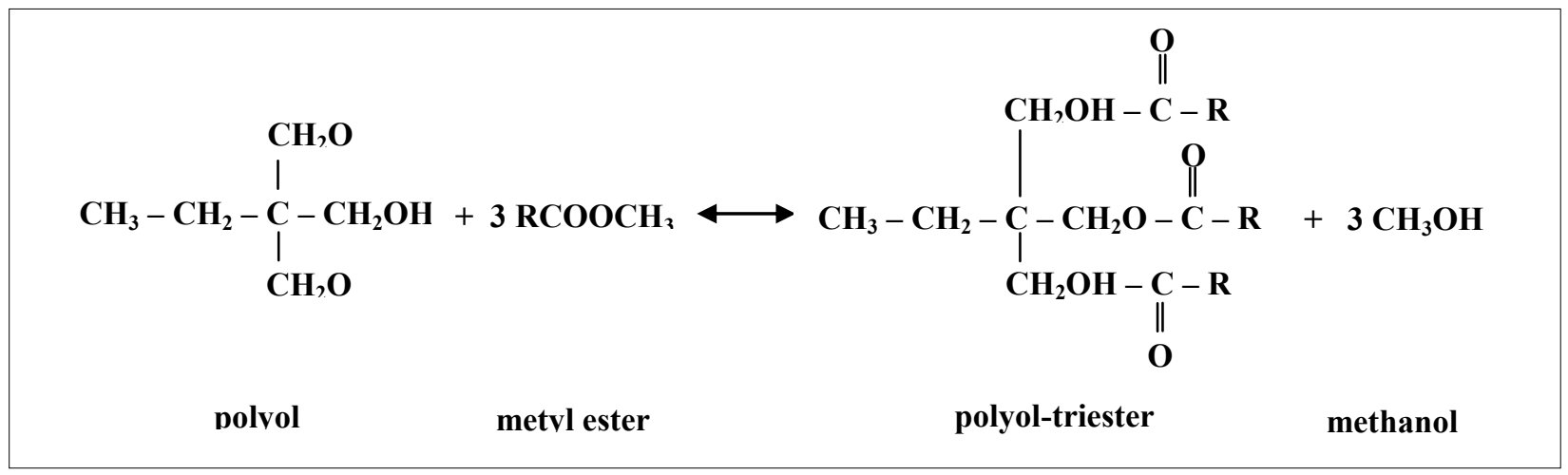

Fig. 2. Transesterification reaction Bio-lubricant [21]

The transesterification process is influenced by the catalyst, contact time, temperature, flow rate, water content in alcohol, the amount of alcohol excesses and free fatty acids in raw materials. The water content in alcohol will result in the formation of soap by consuming a catalyst, and this will reduce the efficiency of the catalyst. To get the maximum conversion, the use of anhydrous alcohol is preferred. Excess alcohol consumption will shift the reaction equilibrium towards the right and the greater the production of methyl ester. Another factor affecting the transesterification process is a free fatty acid content in the raw material. If the free fatty acid content exceeds $0.5 \%$, the saponification reaction will occur in the form of an emulsion. Soap can be physically separated from the former vegetable oils. While the esterification reaction mechanism on biopelumas briefly transesterification contained in Figure 3 below.

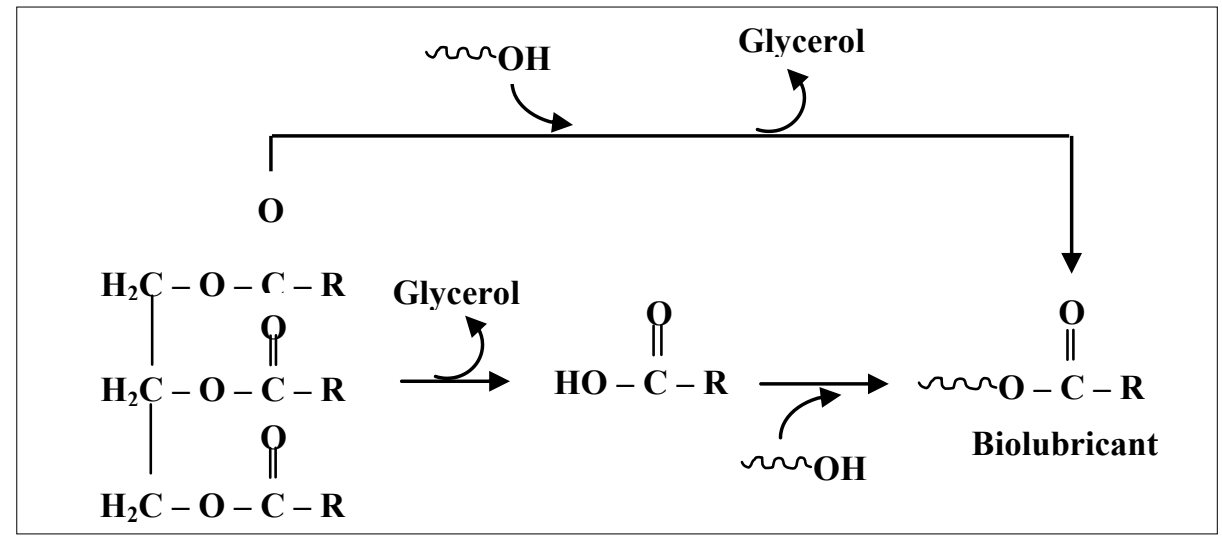

Fig. 3. Esterification Process Scheme (A) and transesterification (B) Bio-lubricant Production [22]

\subsection{Transesterification using sodium methoxide catalyst}

Aziz et al., [23] using raw materials palm oil methyl ester (POME) to produce a bio-lubricant. In this study used sodium methoxide catalyst at a concentration of $0.5 \mathrm{wt} \%, 0.75 \mathrm{wt} \%, 1.0 \mathrm{wt} \%, 1.25 \mathrm{wt} \%$ and $1.5 \mathrm{wt} \%$. Experiments carried out by reacting palm oil methyl ester with pentaerythritol (PEE) and stirring with a speed of $700 \mathrm{rpm}$. Furthermore, the catalyst is added to the mixture and reacted until the designated time. Then the results obtained were separated from the soap and catalyst.

The existence of bio-lubricant products showed by the composition pentaerythrityol tetraoleate (PETO) and trimethylolpropane ester (TMPE) which is the result of a reaction between PEE and POME [24]. The optimal reaction conditions were obtained, namely at a temperature of $158^{\circ} \mathrm{C}$, the catalyst concentration of $1.19 \%$ and a molar ratio of $4.5: 1$ with a reaction time of 60 minutes. From these optimal conditions, the results obtained by the yield of $37.56 \%$, the viscosity at $40^{\circ} \mathrm{C}$ and $100^{\circ} \mathrm{C}$. Zulkifli et al [25] testing the lubrication of biolubricant trimethylolpropane (TMP) and pentaerythritol ester (PE) obtained from POME (palm oil methyl ester) and of the friction value is obtained then this biopelumas fit for use in vehicle engines. Similarly, the results of research by using glycerol [26] and using trimethylolpropane ester [27]. However, to applied bio-lubricant commercially need to increase oxidative stability, thermal and hydrolytic. 


\subsection{Transesterification using oscillatory flow reactor and sodium methoxide catalyst}

Koh et al., [28] undertake the production of biolubricant of palm methyl ester (PME) and trimethylolpropane (TMP) using sodium methoxide catalyst $\left(\mathrm{NaOCH}_{3}\right)$. Then do the transesterification reaction in the oscillatory flow reactor at $110^{\circ} \mathrm{C}$ to $150^{\circ} \mathrm{C}$. An optimal reaction condition was obtained at a temperature of $140^{\circ} \mathrm{C}$ to be reacted for 25 minutes. Bio-lubricant obtained $94.6 \%$ by the concentration diesters $14.7 \%$ and $79.9 \%$ trimesters. However, the lower yield obtained from the research Yunus et al. [29] 2003) with a concentration of $4.6 \%$ diesters and trimesters $93.2 \%$.

Although the results of a study by Koh et al., [28] obtained a high yield, kinematic viscosity and viscosity index which is not accordance with ISO. Bio-lubricant produced has a kinematic viscosity $47.1 \mathrm{cSt}$ at $40^{\circ} \mathrm{C}$, $9.0 \mathrm{cSt}$ at $100^{\circ} \mathrm{C}$ and a viscosity index of 176 . Meanwhile, based on ISO VG100 [30] lubricant should have a kinematic viscosity $>90 \mathrm{cSt}$ at $40^{\circ} \mathrm{C},>4.1 \mathrm{cSt}$ at $100^{\circ} \mathrm{C}$ and a viscosity index $>216$.
Reeves et al. [31] conduct research on the effect of fatty acid composition of the viscosity index contained in the avocado seed oil, canola oil, corn oil, olive oil, peanut oil, safflower oil, sesame oil and soy oil. The result showed that the fatty acid composition affects the viscosity grades, with the highest viscosity in peanut oil for $70.24 \mathrm{cP}$. Based on Zubaidah et al. [32] research used palm oil derivative compounds (trimetylolpropane) as bio-lubricant raw material. Production trimetylolpropane performed using a vacuum reactor with transesterification reaction. From this study showed that the highest conversions were achieved by $66 \%$ at a temperature operating conditions $120^{\circ} \mathrm{C}$ for 2 hours. Syaima et al. [33] produce biolubricant from palm oil mill effluent (POME). Production of bio-lubricant performed using enzymatic hydrolysis and esterification. From the research, optimum reaction conditions reached at $40^{\circ} \mathrm{C}, \mathrm{pH} 7$, stirring speed of $650 \mathrm{rpm}$, the composition of the enzyme $20 \mathrm{U} / \mathrm{ml}$ and $50 \%(\mathrm{v} / \mathrm{v})$ POME.

The research results bio-lubricant using processes esterification/transesterification is shown in Table 4.

Table 4. Characteristics of Bio-lubricant using esterification/transesterification process [17]

\begin{tabular}{|c|c|c|c|c|c|c|c|c|c|}
\hline Reactants & Product & Catalyst & $\begin{array}{l}\text { Reaction } \\
\text { conditions }\end{array}$ & $\begin{array}{l}\text { Viscosity } \\
40^{\circ} \mathrm{C}(\mathrm{cSt})\end{array}$ & $\begin{array}{c}\text { Viscosity } \\
100^{\circ} \mathrm{C}(\mathrm{cSt})\end{array}$ & $\begin{array}{l}\text { Viscosity } \\
\text { index }\end{array}$ & $\begin{array}{l}\text { Pour } \\
\text { point } \\
\left({ }^{\circ} \mathrm{C}\right)\end{array}$ & $\begin{array}{c}\text { Oxidative/ } \\
\text { Thermal } \\
\text { stability }\end{array}$ & $\begin{array}{c}\text { Yield } \\
(\%)\end{array}$ \\
\hline $\begin{array}{l}\text { Jatropha and } \\
\text { TMP }\end{array}$ & $\begin{array}{l}\text { TMP } \\
\text { triesters }\end{array}$ & $\begin{array}{l}\text { Sodium } \\
\text { methoxide }\end{array}$ & $\begin{array}{l}150^{\circ} \mathrm{C}, \\
10 \mathrm{mbar}, 3 \mathrm{~h}\end{array}$ & 43.90 & 8.71 & 180 & -6 & - & $>80$ \\
\hline $\begin{array}{l}\text { Jatropha ME } \\
\text { and TMP }\end{array}$ & $\begin{array}{l}\text { TMP } \\
\text { triesters }\end{array}$ & $\begin{array}{l}\text { Sodium } \\
\text { methoxide }\end{array}$ & $\begin{array}{l}150^{\circ} \mathrm{C}, \quad 55 \\
\min \end{array}$ & 42.57 & 9.37 & 183 & -6 & $\begin{array}{l}325^{\circ} \mathrm{C} \\
\text { Degradation } \\
\text { temp }\end{array}$ & - \\
\hline $\begin{array}{l}\text { High oleic } \\
\text { palm } \\
\text { and TMP }\end{array}$ & $\begin{array}{l}\text { TMP } \\
\text { triesters }\end{array}$ & $\begin{array}{l}\text { Sodium } \\
\text { methoxide }\end{array}$ & $\begin{array}{l}120-150^{\circ} \mathrm{C}, \\
0,3 \text { mbar, } 45 \\
\text { min }\end{array}$ & $45.5-50.7$ & $9.2-10$ & $183-200$ & $\begin{array}{l}(-37) \text { to } \\
(-9)\end{array}$ & - & - \\
\hline $\begin{array}{l}\text { Palm ME } \\
\text { and TMP }\end{array}$ & $\begin{array}{l}\text { TMP } \\
\text { triesters }\end{array}$ & $\begin{array}{l}\text { Sodium } \\
\text { methoxide }\end{array}$ & $\begin{array}{l}140^{\circ} \mathrm{C}, \quad 25 \\
\text { mbar, } \\
\text { min, } \\
\text { oscillatory } \\
\text { flow reactor } \\
\text { at } 1,5 \mathrm{~Hz} \\
\text { with } 20 \mathrm{~mm} \\
\text { amplitude }\end{array}$ & 47.1 & 9.0 & 176 & -2 & $\begin{array}{l}355^{\circ} \mathrm{C} \\
\text { Degradation } \\
\text { temp }\end{array}$ & 94.6 \\
\hline $\begin{array}{l}\text { Palm ME } \\
\text { and TMP }\end{array}$ & $\begin{array}{l}\text { TMP } \\
\text { triesters }\end{array}$ & $\begin{array}{l}\text { Calcium } \\
\text { methoxide }\end{array}$ & $\begin{array}{l}180^{\circ} \mathrm{C}, \quad 50 \\
\text { mbar, } 8 \mathrm{~h}\end{array}$ & - & - & - & - & - & 92,38 \\
\hline $\begin{array}{l}\text { Canola } \\
\text { biodiesel } \\
\text { ME and } \\
\text { TMP }\end{array}$ & $\begin{array}{l}\text { TMP } \\
\text { triester }\end{array}$ & $\begin{array}{l}\text { Sodium } \\
\text { methoxide }\end{array}$ & $\begin{array}{l}110^{\circ} \mathrm{C}, 1 \\
\mathrm{mbar}, 5 \mathrm{~h}\end{array}$ & 40.5 & 7.8 & 204 & -66 & $\begin{array}{l}\text { Induction time: } \\
0.74 \mathrm{~h}\end{array}$ & 90.9 \\
\hline $\begin{array}{l}\text { Castor } \\
\text { biodiesel and } \\
\text { TMP }\end{array}$ & $\begin{array}{l}\text { TMP } \\
\text { triester }\end{array}$ & $\begin{array}{l}\text { Dibutyltin } \\
\text { dilaurate }\end{array}$ & $\begin{array}{l}170^{\circ} \mathrm{C}, 0.01 \\
\text { bar }\end{array}$ & 287.2 & 26.13 & 119 & -27 & $\begin{array}{l}\text { RPVOT: } 43 \mathrm{~min} \\
\text { (Butylated } \\
\text { hydroxytoluene } \\
\text { added) }\end{array}$ & 89.7 \\
\hline $\begin{array}{l}\text { Castor } \\
\text { biodiesel and } \\
\text { TMP }\end{array}$ & $\begin{array}{l}\text { TMP } \\
\text { triester }\end{array}$ & $\begin{array}{l}\text { Amberlyst } \\
15 \text { ionic } \\
\text { exchange } \\
\text { resin }\end{array}$ & $\begin{array}{l}120^{\circ} \mathrm{C}, 0.01 \\
\text { bar }\end{array}$ & 20.94 & 4.467 & 127 & - & - & - \\
\hline $\begin{array}{l}\text { Castor } \\
\text { biodiesel and } \\
\text { TMP }\end{array}$ & $\begin{array}{l}\text { TMP } \\
\text { triester }\end{array}$ & $\begin{array}{l}\text { Sodium } \\
\text { methoxide }\end{array}$ & $\begin{array}{l}120^{\circ} \mathrm{C}, 0.01 \\
\text { bar }\end{array}$ & 11.28 & 3.100 & 141 & - & $\begin{array}{l}\text { RPVOT: } 150 \\
\text { min (Butylated } \\
\text { hydroxytoluene } \\
\text { added) }\end{array}$ & - \\
\hline $\begin{array}{l}\text { WCO ME } \\
\text { and TMP }\end{array}$ & $\begin{array}{l}\text { TMP } \\
\text { triester }\end{array}$ & $\mathrm{KOH}$ & $\begin{array}{l}128^{\circ} \mathrm{C}, \quad 200 \\
\mathrm{~Pa}, 1.5 \mathrm{~h}\end{array}$ & 38.60 & 8.44 & 204 & -8 & FP: $240^{\circ} \mathrm{C}$ & 85.7 \\
\hline
\end{tabular}




\begin{tabular}{|c|c|c|c|c|c|c|c|c|c|}
\hline $\begin{array}{l}\text { Soybean oil } \\
\text { and various } \\
\text { alcohols }\end{array}$ & $\begin{array}{l}\mathrm{n}- \\
\text { alcohol- } \\
\text { esters }\end{array}$ & $\begin{array}{l}\text { Sulfated } \\
\text { zirconia } \\
\text { catalysts } \\
\end{array}$ & $140^{\circ} \mathrm{C}, 4 \mathrm{~h}$ & $10.3-432.7$ & $3.0-34.4$ & $45-195$ & - & - & $>80$ \\
\hline $\begin{array}{l}\text { Sunflower } \\
\text { oil and } \\
\text { octanol }\end{array}$ & $\begin{array}{l}\text { FA-n- } \\
\text { octyl } \\
\text { esters }\end{array}$ & $\begin{array}{l}\text { Fe-Zn } \\
\text { double- } \\
\text { metal } \\
\text { cyanide } \\
\text { (DMC) } \\
\text { complexes }\end{array}$ & $170^{\circ} \mathrm{C}, 8 \mathrm{~h}$ & 7.93 & 2.74 & 226 & -3 & $23 \mathrm{~min}(\mathrm{RBOT})$ & 98 \\
\hline $\begin{array}{l}\text { Valeric acid } \\
\text { TMP }\end{array}$ & $\begin{array}{l}\text { Valeric } \\
\text { acid TMP } \\
\text { ester }\end{array}$ & $\begin{array}{l}\text { Silica- } \\
\text { sulphuric } \\
\text { acid }\end{array}$ & $\begin{array}{l}70^{\circ} \mathrm{C} \text { molar } \\
\text { ratio of } 3: 1 \text {, } \\
\text { toluene }\end{array}$ & 9.5 & 2.5 & 80 & -75 & - & - \\
\hline $\begin{array}{l}\text { Rapeseed } \\
\mathrm{ME} \text { and } \\
\mathrm{NPG} / \mathrm{TMP} / \mathrm{P} \\
\mathrm{E}\end{array}$ & $\begin{array}{l}\mathrm{NPG} / \mathrm{TM} \\
\mathrm{P} / \mathrm{PE} \\
\text { triesters }\end{array}$ & $\begin{array}{l}\text { C } \\
\text { Antarctica } \\
\text { lipase }\end{array}$ & $\begin{array}{l}150,200,50 \\
\mathrm{~h}\end{array}$ & $7.8-38.2$ & $2.7-8.4$ & $205-224$ & $\begin{array}{l}(-31.3) \\
\text { to }(-18)\end{array}$ & $\begin{array}{l}\Delta \mathrm{v}: 90.1-147.1 \\
\Delta \text { Ac: } 2.9-7.7\end{array}$ & 98 \\
\hline $\begin{array}{l}\text { Thumba } \\
\text { ME, xylene } \\
\text { and } \\
\text { NPG/TMP/P } \\
\text { E }\end{array}$ & $\begin{array}{l}\mathrm{NPG} / \mathrm{TM} \\
\mathrm{P} / \mathrm{PE} \\
\text { triesters }\end{array}$ & $\begin{array}{l}\text { p- } \\
\text { Toluensul } \\
\text { phonic } \\
\text { acid }\end{array}$ & $\begin{array}{l}135-140^{\circ} \mathrm{C}, \\
\text { until } \\
\text { complete }\end{array}$ & $20.65-60.26$ & $5.45-11.89$ & $209-220$ & $\begin{array}{l}(-12) \text { to } \\
(-3)\end{array}$ & $\begin{array}{l}10-15 \quad \min \\
(\mathrm{RBOT}) \\
\mathrm{FP}: 270-318^{\circ} \mathrm{C}\end{array}$ & $89-95$ \\
\hline
\end{tabular}

\section{Conclusion}

Increasing the amount of environmental pollution can be solved by replacing petroleum lubricant with biolubricant those have made from vegetable oils. This is because the use of petroleum lubricant gives big influence on environmental pollution because of their lubricant spills which can damage the ecosystem. However, the production of bio-lubricant has not done commercially. Besides bio-lubricant properties are easily damaged so we need more research to improve the shelf life of the bio-lubricant. In addition, research must be done to improve the characteristics by adding a bio-lubricant additive.

\section{References}

1. Precidential Decree Republic of Indonesia No.5. National Energy Policy, (2006).

2. Y. Gerbig, S.I.U. Ahmed, F.A. Gerbig, H. Haefke. Journal of Synthesis Lubricant, 21, 177-191 (2004).

3. BPS. Produksi Bahan Bakar Minyak, (2014).

4. S.C. Tung, M.L. McMillan. Tribology International Journal, 37, 517-536 (2004).

5. S. Asadauskas, J.M. Perez, J.I. Duda. Lubricant Engineering, 52, 877-82 (1996).

6. S.Z. Erhan, S. Asadauskas. Journal of Industrial Crops and Products, 11, 277-282 (2000).
7. N.H. Jayadas, K.P. Nair, G. Ajithkumar, G. Tribology International Journal, 40, 350-354 (2007).

8. S.M. Alves, B.S. Barros, M.F. Trajano, K.S.B Ribeiro, E. Moura. Tribology International Journal, 65, 28-36 (2013).

9. P. Lathi, B. Mattiasson. Journal of Applied Catalyst B: Environment, 69, 207-212 (2007).

10. P. Nagendramma, S. Kaul. Journal of Renewable and Sustainable Energy Review, 16, 764-774 (2012).

11. M. Shahabuddin, H.H. Masjuki, M.A. Kalam, M.M.K. Bhuiya, H. Mehat. Journal of Industrial Crops and Products, 47, 323-330 (2013).

12. K. Saroj, S.R.K. Padhi. Journal of Chemical Pharmacy, 3, 39-49 (2011).

13. H.C. Ong, T.M.I. Mahlia, H.H. Masjuki, R.S. Norhasyima. Journal of Renewable and Sustainable Energy Review, 15, 3501-3515 (2011).

14. R.V. Sharma, K.D. Ajay. Journal of Applied Catalyst B: Environment, 142, 604-614 (2013).

15. D. Kania, Y. Robiah, O. Rozita, A.R. Suraya, M.J. Badrul. Journal of Petroleum Science and Engineering, 135, 177-184 (2015).

16. Z.E. Sevim, A. Atanu, K.S. Brajendra. Journal of Synthetic Lubrication, 17, 22 (2006).

17. J. McNutt, S.H. Quan. Journal of Industrial and Engineering Chemistry, 36, 1-12 (2016).

18. Department of Ecology.. Biolubricants. Environmentally Preferable Purchasing Fact Sheet, Publication No. 13-07-011, (2011). 
19. J.C.J. Bart, G. Emmanuele, C. Stefano. Biolubricants Science and Technology, (2013).

20. M. Hajar, V. Farzaneh. Journal of Industrial Crops and Products, 59, 252-259 (2014).

21. M.F.M.G. Resul, T.I.M. Ghazi, A. Idris. Journal of Industrial Crops and Products, 38, 87-92 (2012).

22. J. Oh, Y. Sungeun, K. Chanyeon, C. Inchang, H.K. Jae. Journal of Applied Catalysis A: General, 455, 164-171 (2013).

23. N.A.M. Aziz, Y. Robiah, R. Umer, M.S. Azhari. Industrial Crops and Products, 62, 305-312 (2014).

24. R. Yunus, A. Fakhru'l-Razi, T.L. Ooi, R. Omar, A. Idris. Industrial Engineering Chemical, 44, 81788183 (2005).

25. N.W.M. Zulkifli, S.S.N. Azman, M.A. Kalam, H.H. Masjuki, R. Yunus, M. Gulzar. Tribology International, 93, 555-562 (2016).

26. G.S. Dodos, D. Karonis, F. Zannikos, E. Lois. Journal of Industrial Crops and Products, 75, 4350 (2015).

27. H.A. Hamid, R. Yunus, U. Rashid, T.S.Y. Choong, A.H. Al-Muhtaseb. Chemical Engineering Journal, 200-202, 532-540 (2012).

28. M.Y. Koh., I.M.G. Tinia, I. Azni. Journal of Industrial Crops and Products, 52, 567-574 (2014).

29. M.S. Silva, E.L. Foletto, S.M. Alves, T.N.C. Dantas, A.A.D. Neto. Journal of Industrial Crops and Products, 69, 362-370 (2015).

30. L.R. Rudnick, S.Z. Erhan. Natural oils as lubricants, (2006).

31. C.J. Reeves, L.M. Pradeep, J. Tien-Chien, R.L. Michael. Tribology International Journal, 90, 123134 (2015).

32. S.S. Zubaidah, A.C. Luqman, A. Fakhru'l-Razi. Journal of Applied Energy, 7 (15): 2002-2005 (2007).

33. M.T.S. Syaima, K.H. Ong, M.N. Ishenny, M.I.M. Zamratul, S.A. Brahim. Journal of Renewable and Sustainable Energy Reviews, 44: 669-675 (2015). 